\title{
Performance of pre-sprouted sugarcane seedlings in response to the application of humic acid and plant growth-promoting bacteria
}

\author{
Desempenho de mudas pré-brotadas de cana-de-açúcar em \\ resposta a aplicação de ácidos húmicos e bactérias promotoras do \\ crescimento vegetal
}

\author{
Hend Pereira de Oliveira ${ }^{1}$; Raphael Oliveira de $\mathrm{Melo}^{2}$; Marihus Altoé Baldotto \\ Messias Antônio Andrade ${ }^{3}$; Lílian Estrela Borges Baldotto ${ }^{3 *}$
}

\begin{abstract}
Sugarcane cultivation using pre-sprouted seedlings has decreased the number of stalks used per hectare, increased the multiplication rate, improved seedling health, and increased planting uniformity. However, because this system has been only recently proposed, the number of studies evaluating this new technology is still scarce, particularly those examining the effect of the application of growth-promoting substances on seedling characteristics during the production phase. Here, we hypothesized that it is possible to combine the plant growth-promoting activity of humic acid (HA) with the inoculation of selected strains of plant growth-promoting bacteria (PGPB) to improve the yield of sugarcane seedlings compared with the individual application of these two techniques. The potential of the combined use of HA and PGPB as agricultural inputs was evaluated by conducting an experiment with sugarcane micro cuttings in a greenhouse. Treatments included control, PGPB, HA, and PGPB with HA. At the end of the experiment ( $60 \mathrm{~d}$ after planting), the plants were subjected to biometric evaluation. The results indicated that it was possible to combine HA with selected strains of PGPB (Burkholderia sp.) to improve the yield of seedlings compared with individual HA and PGPB treatments. HA, PGPB, and HA + PGPB increased the total dry matter compared with the control by $23 \%, 25 \%$, and $36 \%$, respectively. Therefore, the use of HA-based plant regulators in combination with PGPB was more effective than the isolated use of these inputs for the treatment of micro cuttings and improvement of sugarcane seedling yield.
\end{abstract}

Key words: Burkholderia sp. Diazotrophic bacteria. Humic substances. Saccharum officinarum. Soil organic matter.

\section{Resumo}

O cultivo da cana-de-açúcar com mudas pré-brotadas tem permitido a redução do volume gasto de colmos por hectare, o aumento da taxa de multiplicação, da sanidade das mudas e da uniformidade do plantio. Contudo, por ter sido proposto há pouco tempo, o número de trabalhos com essa nova tecnologia ainda é escasso, especialmente quanto ao comportamento dessas mudas frente à inoculação com bactérias promotoras de crescimento de plantas. Hipótese desse trabalho propõe que é possível

${ }^{1}$ Eng $^{\mathrm{a}}$ Agr ${ }^{\mathrm{a}}$, Analista de Qualidade da Empresa Hidrosabor®, Florestal, MG, Brasil. E-mail: hend@hidrosabor.com.br

2 Discente, Curso de Doutorado, Programa de Pós-Graduação em Solos e Nutrição de Plantas, Universidade Federal de Viçosa, Viçosa, MG, Brasil. E-mail: raphael.o.melo@ufv.br

3 Profs., Instituto de Ciências Agrárias, Universidade Federal de Viçosa, Campus Florestal, UFV/CAF, Florestal, MG, Brasil. E-mail:marihus@ufv.br; messias@ufv.br; lilian.estrela@ufv.br; liestrelaborges@gmail.com

* Author for correspondence

Received: Oct. 20, 2017 - Approved: Mar. 21, 2018 
combinar o efeito de promoção do crescimento vegetal dos ácidos húmicos (AH) com a inoculação de estirpes selecionadas de bactérias promotoras de crescimento de plantas (BPCP) com vias a obtenção de respostas superiores à aplicação isolada de ambos na produção mudas de cana de açúcar. Para avaliar o potencial do uso combinado de AH e bactérias diazotróficas endofíticas como insumo agrícola, foi instalado um experimento com microtoletes de cana-de-açúcar em casa de vegetação. Os tratamentos incluiram o controle, BPCP, AH e BPCP com AH. Ao final do experimento (60 dias após o plantio) as plantas foram avaliadas biometricamente. Os resultados demonstraram ser possível combinar os efeito dos AH com a inoculação de estirpes selecionadas de BPCP (Burkholderia sp.) com maior desenvolvimento das mudas comparadas com o tratamento isolado com AH e BPCP. AH, BPCP, e AH + BPCP aumentaram a matéria seca total em $23 \%, 25 \%$, e $36 \%$, com relação ao controle respectivamente. Assim, o uso de biorreguladores a base de AH combinados com BPCP é positivo e complementar comparativamente aos insumos geralmente usados no tratamento de microtoletes para a produção de mudas de cana de açúcar.

Palavras-chave: Bactérias diazotróficas. Burkholderia sp. Matéria orgânica do solo. Saccharum officinarum. Substâncias húmicas.

At present, sugarcane (Saccharum spp.) is one of the most important crops in Brazil, where sugar and alcohol-based agribusiness accounts for approximately $2 \%$ of the national GDP. It is also one of the most labor-intensive production sectors in Brazil (UNIÃO DA INDUSTRIA DE CANA-DEAÇÚCAR, 2015). Increases in the cultivated area of sugarcane have increased the demand for novel production technologies. Therefore, the search for alternatives that reduce environmental impacts and promote productivity gains.

The planting stage of sugarcane must be well planned because the decisions made in this phase will affect the entire production cycle (BARROS; MILAN, 2010). With the advent of mechanical planting, failures have become more frequent; this has led to an increase in the volume of seedlings used in cultivation to prevent significant productivity losses. The increase in these volumes to above 20 tons/ha poses problems related to transportation, handling, and storage, in another situation these stalks could be better used in the industry. In addition the high number of stalks in groove generates an execessive number of seedlings, create competition for water, light and nutrients (LANDELL et al., 2012).

In this context, the use of pre-sprouted seedlings (PPS) is promising because it increases seedling production rates and ensures plant health, vigor, and adequate planting uniformity. This system has reduced the volume of stalks used per hectare and has increased the multiplication rate; it also uses a smaller volume of material in the field, facilitating planting stage operations (LANDEL et al., 2012). The search for plants with high standards of vigor and sanity has taken to the use of MPB in the planting system denominated MEIOSE (Methods Inter-rotational Occurring Simultaneously) which consists of the implantation of a nursery system in the area of commercial farming that is desired to originate (PROCANA, 2017). As PPS production has been only recently proposed, few studies have evaluated this new technology to date, and little is known about the effect of inoculating these seedlings with plant growth-promoting bacteria (PGPB) in the production phase.

The use of diazotrophic PGPB has the potential to reduce the dependence of several crops on synthetic nitrogen fertilizers, allowing economic gains and decreasing environmental impacts, for sugarcane, inoculation with PGPB can fully or partially replace the use of nitrogen fertilizers (GÍRIO et al., 2015). Pereira et al. (2013) found that some plant varieties, when inoculated, accumulate more dry matter than when treated with nitrogen fertilizer. Among the PGPB species, the genus Burkholderia, have a distribution in the Poaceae family with species 
associated to sugarcane capable to promote plant growth (CASTRO-GONZÁLEZ et al., 2011).

PGPB directly promote plant growth via several mechanisms, including the production of organic acids, phytohormones, enzymes, mineralization of nutrients, solubilization of phosphates, nitrogen fixation, and increasing root absorption (COMPANT et al., 2010). Studies have demonstrated that the use of microorganisms in the form of inoculants represents a strategic method of reducing dependence on inputs derived from nonrenewable, polluting, and economically unsustainable energy sources (GÍRIO et al., 2015; COMPANT et al., 2010).

Humic acids (HA) applied in combination with PGPB can enhance plant growth (CANELLAS et al., 2013; BALDOTTO et al., 2010). This effect may be due to increases in rooting and the number of mitotic sites, and the emergence of lateral roots, all of which increase the number of potential bacterial infection sites (MARQUES JÚNIOR et al., 2008). Here, we hypothesized that it is possible to combine the plant growth-promoting effect of HA and inoculation with selected strains of endophytic diazotrophic PGPB to improve the yield of seedlings compared with the individual application of these methods on pre-sprouted sugarcane seedlings growth.

The experiment was conducted in September to November 2015 at the Florestal Campus of the Federal University of Viçosa (Campus Florestal da Universidade Federal de Viçosa, CAF-UFV; $19^{\circ} 52^{\prime} 16.3^{\prime \prime} \mathrm{S}$ and $44^{\circ} 25^{\prime} 26.1^{\prime \prime} \mathrm{W}$ ) located at an altitude of approximately $750 \mathrm{~m}$.

HA were isolated from cattle dung composted, that was collected in the stable at CAF-UFV. The isolation of humic acids was performed using the method suggested by the International Humic Substances Society, by preparing a 1: $10(\mathrm{v} / \mathrm{v})$ extract from an organic compound prepared, in a solution of sodium hydroxide $\mathrm{NaOH}$ with a concentration of $0.1 \mathrm{~mol} \mathrm{~L}^{-1}$. After stirring for 4 hours, the extract was decanted, resulting in an insoluble precipitate called the humin fraction (which was not used in this study) and a supernatant solution containing humic and fulvic acids. The $\mathrm{pH}$ of the supernatant was adjusted to between 1 and 1.5 , with $6 \mathrm{~mol} \mathrm{~L}^{-1}$ $\mathrm{HCl}$, and the extract was separated, resulting in a supernatant solution containing fulvic acids (also discarded in this study), and a precipitate of humic acids, used as a biostimulant for plants.

One colony, Burkholderia gladioli was inoculated in $5 \mathrm{~mL}$ of liquid DYGS medium (RODRIGUES NETO et al., 1986) and incubated at $30^{\circ} \mathrm{C}$ with shaking (150 rpm) for $24 \mathrm{~h}$. A $30-\mu \mathrm{L}$ aliquot of the mature culture was transferred to a $12-\mathrm{mL}$ glass flask containing $5 \mathrm{~mL}$ of JMV semisolid culture. Bacteria were grown at $30^{\circ} \mathrm{C}$ for $72 \mathrm{~h}$.

Three-centimeter-long micro cuttings of the cultivar Ridesa Brasil (RB) 867515 were obtained using the PPS multiplication system (LANDELL et al., 2012). The cuttings were immersed in their respective treatment solutions: $\mathrm{HA}$ at a concentration of $23 \mathrm{mmol} \mathrm{L}^{-1}$ was extracted from cattle dung (MELO et al., 2015) for $16 \mathrm{~h}$ and from the bacterial solution $\left(131 \times 10^{3}\right.$ colony-forming units per milliliter) for $2 \mathrm{~h}$. The control was immersed in water for $18 \mathrm{~h}$ and the micro cuttings were immersed in the treatment solution.

After this procedure, the micro cuttings were transferred to $180 \mathrm{~cm}^{3}$ tubes and treated with the Bioplant ${ }^{\circledR}$ substrate that contained $5.2 \mathrm{~g} \mathrm{~kg}^{-1}$ of $\mathrm{N}$, $2.0 \mathrm{~g} \mathrm{~kg}^{-1}$ of $\mathrm{P}_{2} \mathrm{O}_{5}, 2.9 \mathrm{~g} \mathrm{~kg}^{-1}$ of $\mathrm{K}_{2} \mathrm{O}, 13.1 \mathrm{~g} \mathrm{~kg}^{-1}$ of $\mathrm{CaO}, 5.6 \mathrm{~g} \mathrm{~kg}^{-1}$ of $\mathrm{MgO}$, and $2.4 \mathrm{~g} \mathrm{~kg}^{-1}$ of $\mathrm{S}$, at a (pH 5.8).

The experiment was conducted in greenhouse using a fully randomized design and included four treatments (control, PGPB, HA, and HA + PGPB) and seven repetitions, with each repetition consisting of two experimental units, totaling 28 experimental units.

The following variables were determined at the end of the experiment ( 60 days after planting): plant height, the number of leaves, the width of the central region of the largest leaf, length of the largest 
leaf, and stem diameter. For sample collection, the plants were cut close to the substrate, and the fresh matter of the aboveground part was determined. The roots were separated from their substrate and washed in running water before the fresh matter was determined. Both the aboveground section and the root system were placed in paper bags and maintained in a forced-air ventilation kiln at $60^{\circ} \mathrm{C}$ for $72 \mathrm{~h}$ for complete drying of the plant material and determination of the aboveground dry matter of the aerial part (DMAP) and dry root matter (DRM). The sum of DMAP and DRM yielded the total dry matter (TDM). The data were subjected to variance analysis and the means of the treatments were compared using the Tukey test $(P \leq 0.05)$.

The results indicated that the performance of sugarcane seedlings was affected by inoculation with endophytic diazotrophic PGPB and HA when compared with the control (Table 1). Our results were similar to those of Gírio et al. (2015), wherein the inoculation of PPS with PGPB promoted plant growth by increasing the biomass of the root and aboveground parts of seedlings. The increase observed in seedlings can be attributed to the capacity of the microorganisms to produce phytohormones including indole acetic acid, ethylene, cytokinins, and gibberellins, that stimulate plant growth (COMPANT et al., 2010). MuñozRojas and Mellado-Caballero (2003) concluded that the increased growth of the aboveground parts of sugarcane seedlings after bacterial inoculation depended on the sugarcane variety and bacterial strain used. Our results were consistent with those of Marques Júnior et al. (2008), who observed that the inoculation of micro cuttings with PGPB and treatment with HA strongly affected total dry matter and root dry matter. The physiological effect of HA may be associated with the presence of chemical compounds with structures similar to those of plant hormones (CANELLAS et al., 2013), these mechanisms can explain the significant effects of HA on micro cuttings.

Table 1. Mean values of the biometric characteristics: plant height (PH), number of leaves (NL), width of the largest leaf (WLL), stem diameter (SD), fresh matter of the above-ground part (AGFM), dry matter of the aboveground part (AGDM), root fresh matter (RFM); root dry matter (RDM), and total dry matter (TDM), of pre-sprouted sugarcane treated with the humic acid (HA), endophytic diazotrophic plant-growth promoting bacteria (PGPB), and a combination of HA and PGPB (HA + PGPB).

\begin{tabular}{|c|c|c|c|c|c|c|c|c|c|c|}
\hline Treat & $\mathrm{PH}$ & $\mathrm{NL}$ & WLL & $\mathrm{CF}$ & SD & AGFM & RFM & AGDM & RDM & TDM \\
\hline & $\mathrm{cm}$ & & 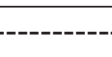 & $\mathrm{cm}---$ & --- & $\ldots$ & -2 & g per $p l$ & 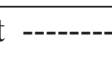 & --- \\
\hline Control & $60.36 \mathrm{~b}$ & $4.43 \mathrm{~b}$ & $1.19 \mathrm{a}$ & $48.86 \mathrm{~b}$ & $1.11 \mathrm{~b}$ & $3.54 \mathrm{c}$ & $0.42 \mathrm{c}$ & $1.10 \mathrm{c}$ & $0.26 \mathrm{~b}$ & $1.39 \mathrm{c}$ \\
\hline HA & $69.86 \mathrm{a}$ & $5.13 \mathrm{a}$ & $1.25 \mathrm{a}$ & $56.63 \mathrm{a}$ & $1.21 \mathrm{ab}$ & $6.89 \mathrm{~b}$ & $0.73 \mathrm{~b}$ & $1.46 \mathrm{~b}$ & $0.34 \mathrm{a}$ & $1.81 \mathrm{~b}$ \\
\hline PGPB & $67.36 \mathrm{a}$ & $5.00 \mathrm{a}$ & $1.30 \mathrm{a}$ & $54.86 \mathrm{a}$ & $1.21 \mathrm{ab}$ & $6.44 \mathrm{~b}$ & $0.70 \mathrm{~b}$ & $1.50 \mathrm{~b}$ & $0.36 \mathrm{a}$ & $1.86 \mathrm{~b}$ \\
\hline $\mathrm{HA}+\mathrm{PGPB}$ & $71.43 \mathrm{a}$ & $5.29 \mathrm{a}$ & $1.30 \mathrm{a}$ & $57.74 \mathrm{a}$ & $1.24 \mathrm{ab}$ & $8.55 \mathrm{a}$ & $0.91 \mathrm{a}$ & $1.77 \mathrm{a}$ & $0.39 \mathrm{a}$ & $2.16 \mathrm{a}$ \\
\hline CV (\%) & 5.05 & 8.22 & 7.60 & 4.16 & 5.47 & 16.18 & 14.51 & 12.30 & 12.77 & 11.44 \\
\hline
\end{tabular}

Means followed by the same letters were not significantly different $(P \leq 0.05)$, calculated using Tukey test.

Our results also indicated that the combination of the growth-promoting effect of $\mathrm{HA}$ and inoculation with selected strains of PGPB improved the yield of seedlings compared with the individual application of these methods, this synergistic effect increased root fresh matter, aboveground fresh matter, aboveground dry matter, and total dry matter (Table 1). These results corroborate the findings of Marques Júnior et al. (2008) relating to the effect of the joint application of Herbaspirillum seropedicae bacteria and HA isolated from vermicompost on sugarcane micro cuttings. Similar results were 
found in several crops, Canellas et al. (2013) observed that the application of HA isolated from vermicompost at $20 \mathrm{mg}$ of $\mathrm{C} \mathrm{L}^{-1}$ applied through seed treatment, stimulated lateral growth of maize roots favoring a greater colonization inside the plants by Herbaspirillum seropedicae, increased maize grain production $65 \%$, when compared to control. Baldotto et al. (2010) observed that the application of Burkholderia sp. and HA isolated from vermicompost improved the yield of pineapple plants compared with the individual application of these methods.

The PGPB infection process occurs from its penetration into plant tissue through small openings created by new lateral roots emergence, and by roots and/or in the rhizosphere ion transport process (CANELLAS et al., 2013). The positive influence of HA on the PGPB in the plant occurs through biostimulation mechanisms in the root system development, through substances analogous to synthetic growth regulators, such as auxins (TREVISAN et al., 2010), they can provide accelerated activity ATPase activity, assisting in root expansion that increases the sites for PGPB colonization in the roots (MARQUES JÚNIOR et al., 2008).

Almeida et al. (2008) found that increased seedling development improved crop productivity, suggesting that plants with greater initial growth and dry matter accumulation can better harness the available solar radiation at the beginning of the cycle and improve their performance by increasing carbohydrate production. This hypothesis is reinforced by the fact that sugarcane exhibits $\mathrm{C} 4$ metabolism; therefore, its genetic potential is improved by better harnessing solar radiation, and the increased growth of the stimulated seedlings increases their photosynthetic efficiency.

Similarly, the greater initial development of the root system improves productivity by increasing the volume of exploited soil, increasing plant tolerance to stresses-particularly water stress-and the capacity of the roots to absorb nutrients by directly enhancing the root interception mechanism and indirectly increasing mass flow and diffusion.

The results obtained in this study indicate the possibility of using a new biological input based on the combination of PGPB of Burkholderia gladioli and bioactive fractions of organic matter in the form of HA for the formulation of plant regulators. This combination may assist in the development of vigorous seedlings and may represent a valuable method of obtaining higher sugarcane crop yields.

The use of HA isolated from cattle dung at a concentration of $23 \mathrm{mmol} \mathrm{L}^{-1}$, together with the Burkholderia gladioli bacteria, improved the yield of pre-sprouted sugarcane seedlings compared with the individual application of these two methods.

\section{References}

ALMEIDA, A. C. S.; SOUZA, J. L.; TEODORO, I.; BARBOSA, G. V. S.; MOURA FILHO, G.; FERREIRA JÚNIOR, R. A. Desenvolvimento vegetativo e produção de variedades de cana-de-açúcar em relação à disponibilidade hídrica, e unidades térmicas. Ciência e Agrotecnologia, Lavras, v. 32, n. 5, p. 1441-1448, 2008.

BALDOTTO,L.E.B.;BALDOTTO, M.A.; CANELLAS, L. P.; BRESSAN-SMITH, R. E.; OLIVARES, F. L. Growth promotion of pineapple 'Vitória' by humic acids and Burkholderia spp. during acclimatization. Revista Brasileira de Ciência do Solo, Viçosa, MG, v. 34, n. 5, p. 1593-1600, 2010.

BARROS, F. F.; MILAN, M. Qualidade operacional do plantio de cana-de-açúcar. Bragantia, Campinas, v. 69, n. 1, p. 221-229, 2010

CANELLAS, L. P.; BALMORI, D. M.; MÉDICI, L. O.; AGUIAR, N. O.; CAMPOSTRINI, E.; ROSA, R. C.; FAÇANHA, A. R.; OLIVARES, F. L. A. Combination of humic substances and Herbaspirillum seropedicae inoculation enhances the growth of maize (Zea mays L.). Plant and Soil, Dordrecht, v. 366, n. 2, p. 119-132, 2013.

CASTRO-GONZÁLEZ，R.; MARTÍNEZ-AGUILAR, L.; RAMÍREZ-TRUJILLO, A.; ESTRADA-DE LOS SANTOS, P.; CABALLERO-MELLADO, J. High diversity of culturable Burkholderia species associated with sugarcane. Plant and Soil, Dordrecht, v. 345, n. 1-2, p. 155-169, 2011. 
COMPANT, S.; CLÉMENT, C.; SESSITSCH, A. Plant growth-promoting bacteria in the rhizo- and endosphere of plants: their role, colonization, mechanisms involved and prospects for utilization. Soil Biology \& Biochemistry, Elmsford, v. 42, n. 5, p. 669-678, 2010.

GÍRIO, L. A. S.; DIAS, F. L. F.; REIS, V. M.; URQUIAGA, S.; SCHULTZ, N.; BOLONHEZI, D.; MUTTON, M. A. Bactérias promotoras do crescimento e adubação nitrogenada no crescimento inicial de canade-açúcar provenientes de mudas pré-brotadas. Pesquisa Agropecuária Brasileira, Brasília, v. 50, n. 1, p. 33-43, 2015.

LANDELL, M. G. A.; CAMPANA, M. P.; FIGUEIREDO, P. Sistema de multiplicação de cana-de-açúcar com uso de mudas pré-brotadas (MPB), oriundas de gemas individualizadas. Campinas: Instituto Agronômico, 2012. 22 p. (Boletim técnico, 109).

MARQUES JÚNIOR, R. B.; CANELLAS, L. P.; SILVA, L. G.; OLIVARES, F. L. Promoção de enraizamento de microtoletes de cana-de-açúcar pelo uso conjunto de substâncias humicas e bactérias diazotrofícas endofíticas. Revista Brasileira de Ciência do Solo, Viçosa, MG, v. 32, n. 3, p. 1121-1128, 2008.

MElO, R. O.; BALDOTTO, M. A.; BALDOTTO, L. E. B. Corn initial vigor in response to humic acids from bovine manure and poultry litter. Semina: Ciências Agrárias, Londrina, v. 36, n. 1, p. 1863-1874, 2015.
MUÑOZ-ROJAS, J.; MELLADO-CABALLERO, J. Population dynamics of Gluconacetobacter diazotrophicus in sugarcane cultivars and its effect on plant growth. Microbial Ecology, New York, v. 46, n. 4, p. 454-464, 2003.

PEREIRA, W.; LEITE, J. M.; HIPÓlitO, G. S.; SANTOS, C. L. R.; REIS, V. M. Acúmulo de biomassa em variedades de cana-de-açúcar inoculadas com diferentes estirpes de bactérias diazotróficas. Revista Ciência Agronômica, Fortaleza, v. 44, n. 2, p. 363-370, 2013.

PROCANA. Tecnologia agrícola. In: CRUZ, D. C. Jornal da cana. Ribeirão Preto: PROCANA, 2017. v. 278, p. 22-23.

RODRIGUES NETO. J.; MALAVOLTA JÚNIOR, V. A.; VICTOR, O. Meio simples para o isolamento e cultivo de Xanthomonas campestris pv. citri Tipo B. Summa Phytopathologica, São Paulo, v. 12, n. 1-2, p. 16, 1986.

TREVISAN, S.; PIZZEGHELLO, D.; RUPERTI, B.; FRANCIOSO, O.; SASSI, A.; PALME, K.; QUAGGIOTTI, S.; NARDI, S. Humic substances induce lateral root formation and expression. of the early auxinresponsive IAA19 gene and DR5 synthetic element in Arabidopsis. Plant Biology, Stuttgart, v. 12, n. 4, p. 604$614,2010$.

UNIÃO DA INDÚSTRIA DE CANA-DE-AÇÚCAR UNICA. Fotografia do setor sucroenergético no Brasil. São Paulo - SP, 2015. Disponível em: <www.unica.com. br/download.php?idSecao $=17 \& \mathrm{id}=35831777>$. Acesso em: 2 jul. 2017. 